\title{
ESTUDO SOBRE O CONSTITUCIONALISMO PRINCIPIALISTA COMO UMA CONTRAPOSIÇÃO AO CONSENSO NEOCONSTITUCIONALISTA
}

\author{
Raimundo Oliveira Filho ${ }^{1}$ \\ Adriana Fasolo Pilati Scheleder ${ }^{2}$
}

Resumo: O presente artigo tem por objetivo apresentar a teoria constitucionalista garantista, desenvolvida por Luigi Ferrajoli, como contraponto ao consenso neoconstitucionalista no direito brasileiro. Trata-se de uma formulação que enfatiza a normatividade dos princípios constitucionais com o propósito de reduzir o ativismo judicial e, consequentemente, evitar instabilidades no Estado Constitucional de Direito. O método adotado na pesquisa é de análise de fontes (constituições, leis, normas, projetos de lei e projetos de emendas constitucionais) e de pesquisa bibliográfica, histórica, considerando o método dedutivo e empírico, buscando realizar uma análise doutrinária.

Palavras-chave: Direito Constitucional. Constitucionalismo. Garantismo. Neoconstitucionalismo.

\section{STUDY ON PRINCIPALIST CONSTITUTIONALISM AS A CONTRAPOSITION TO THE NEOCONSTITUTIONAL CONSENSUS}

\begin{abstract}
This article aims to present the Guarani constitutionalist theory, developed by Luigi Ferrajoli, as a counterpoint to the neoconstitutionalist consensus in Brazilian law. It is a formulation that emphasizes the normativity of constitutional principles with the purpose of reducing judicial activism and, consequently, avoiding instabilities in the Constitutional State of Law. The method adopted in the research is the analysis of sources (constitutions, laws, norms, bills and projects of constitutional amendments) and of bibliographical, historical research, considering the deductive and empirical method, seeking to carry out a doctrinal analysis.
\end{abstract}

key words: Constitutional right. Constitutionalism. Garantismo. Neo-constitutionalism.

\section{INTRODUÇÃO}

O presente estudo tem por objeto $^{3}$ apresentar as teses do constitucionalismo garantista (ou positivista) e sua contraposição ao neoconstitucionalismo. A partir de uma

\footnotetext{
${ }^{1}$ Doutor em Direito pela UNIVALI, Mestre pela UNITAU, Especialista em Metodologia do Ensino Superior (UNIR), coordenador e professor do Curso de Direito do Centro Universitário São Lucas. E-mail: raimundoadvogado1384@gmail.com.

${ }^{2}$ Docente Titular da Faculdade de Direito da UPF, Doutora em Direito pela, Mestre em Direito pela PUC/RS, professora e coordenadora adjunta do PPGD da UPF. E-mail: apilati@upf.br.
}

Revista de Teorias do Direito e Realismo Jurídico | e-ISSN: 2525-9601 | Porto Alegre | v. 4 | n. 2 |

p. 107 - 129 | Jul/Dez. 2018 
revisão bibliográfica ${ }^{4}$ a respeito do tema, serão traçados, dentro dos limites possíveis em um artigo desta natureza, as definições de neoconstitucionalismo (principialista), constitucionalismo garantista (positivista) e normas (regras e princípios). Após esta delimitação do objeto em análise, serão apresentadas as principais críticas feitas pela teoria garantista ao constitucionalismo principialista, bem como as possíveis consequências negativas de sua aplicação precipitada e irrefletida. Por fim será abordado o tema do ativismo judicial no Brasil sob o ponto de vista do constitucionalismo garantista, o qual repudia a insubordinação de juízes às normas constitucionais (regras e princípios), considerando tal postura uma indevida ofensa à separação entre os poderes.

A reação da teoria constitucional aos horrores observados na Segunda Guerra Mundial modificou completamente o panorama da teoria e prática jurídica, deslocando a constituição, que até então permanecia em posição discreta, para o centro do ordenamento jurídico, passando a ser o fundamento de legitimação e validade de todas as normas e um corpo de normas vinculantes e limitadoras da atuação de governantes e governados.

Como consequência do modelo adotado, a jurisdição constitucional rapidamente se expandiu a territórios jamais imaginados, passando de uma postura passiva para um expresso ativismo judicial. Evidentemente, esta metamorfose, que se operou a partir da segunda metade do século XX e permanece em movimento até os dias atuais, merece ser observada com a devida atenção, uma que, especialmente nas jovens democracias latino-americanas, a estabilidade do Estado Constitucional de Direito muitas vezes é mais delicada do que se imagina.

Salienta-se que a intenção primordial deste estudo não é esgotar o tema e nem tampouco, desacreditar a tradição constitucionalista pátria, mas apenas contribuir com o debate, levantando questionamentos e procurando trazer novos elementos para a compreensão do fenômeno do constitucionalismo no Brasil, afinal somente por intermédio da contraposição de ideias é possível desenvolver a teoria jurídica e, por outro lado, a aceitação de paradigmas preestabelecidos como verdadeiros dogmas inquestionáveis causaria a estagnação intelectual e vulnerabilidade da produção científica.

\footnotetext{
3 “[...] é o motivo temático (ou a causa cognitiva, vale dizer, o conhecimento que se deseja suprir e/ou aprofundar) determinador da realização da investigação". (PASOLD, 2003. p. 170).

${ }^{4}$ Quanto às Técnicas mencionadas v. PASOLD, 2003, p. 61-125.
} 


\section{O NEOCONSTITUCIONALISMO(S)}

Nos últimos anos houve grande produção bibliográfica a respeito do denominado neoconstitucionalismo. No entanto, permanecem "incontáveis imprecisões terminológicas $e$ inúmeras divergências sobre o tema" (TRINDADE, 2012, p.96), de modo que, possivelmente, seria mais adequado falar em neoconstitucionalismos, no plural. O termo é ordinariamente utilizado para referir-se a todas as teorias que, dedicadas ao estudo das modificações ocorridas no paradigma constitucional a partir da segunda metade do século XX, reconhecem, em alguma medida, a normatividade da Constituição perante todos os poderes instituídos, bem como a rigidez constitucional, de modo a evitar alterações súbitas nos sistemas político-jurídico e a supressão dos direitos e garantias constitucionalmente estabelecidos. Nesta perspectiva, Trindade expõe a pluralidade semântica atribuída ao termo neoconstitucionalismo:

Trata-se, com efeito de uma expressão proteica - em alusão a Proteu, deus marinho da mitologia grega, conhecido pela sua capacidade de assumir diversas formas - que ingressou definitivamente no léxico jurídico e vem sendo empregada para se referir às tentativas de explicar as transformações ocorridas no campo do direito a partir da Segunda Guerra Mundial, mas cuja amplitude semântica alcança três níveis:

a) explica as especificidades que caracterizam os textos constitucionais promulgados na segunda metade de século XX, em que se incorporam normas substanciais que condicionam a atuação do Estado da Realização dos fins e objetivos estabelecidos;

b) trata das práticas jurisprudenciais assumidas pelos tribunais e cortes constitucionais, cuja atuação implica parâmetros interpretativos compatíveis com o grau de racionalidade exigido pelas decisões judicias;

c) pressupõe a construção de aportes teóricos para compreender os novos textos constitucionais e aperfeiçoar as novas práticas jurisprudenciais. (TRINDADE, 2012, p.96)

Outro aspecto invariavelmente presente nos estudos denominados neoconstitucionalistas é a relevância conferida à jurisdição constitucional, competindo-lhe garantir os direitos fundamentais e resguardar o Estado Constitucional de Direito e a democracia. Paulo Gustavo Gonet Branco aborda esta questão da seguinte maneira:

Hoje, é possível falar em um momento de constitucionalismo que se caracteriza pela superação da supremacia do Parlamento. O instante atual é marcado pela superioridade da constituição, a que se subordinam todos os poderes por ela constituídos, garantida por mecanismos jurisdicionais de controle de constitucionalidade. A Constituição, além disso, se caracteriza pela absorção de valores morais e políticos (fenômenos por vezes designado como materialização da constituição), sobretudo em um sistema de direitos fundamentais autoaplicáveis. Tudo isso sem prejuízo de se continuar a afirmar a ideia de que o poder deriva do povo, que se manifesta ordinariamente por seus representantes. A esse conjunto de 
fatores, vários autores, sobretudo na Espanha e na América Latina, dão o nome de neoconstitucionalismo.

O atual estádio do constitucionalismo se peculiariza também pela mais aguda tensão entre constitucionalismo e democracia. É intuitivo que o giro de materialização da Constituição limita o âmbito de deliberação política aberto às maiorias democráticas. Como cabe à jurisdição constitucional a última palavra na intepretação da constituição, que se apresenta agora repleta de valores impositivos para todos os órgãos estatais, não surpreende que o juiz constitucional assuma parcela de mais considerável poder sobre as deliberações políticas de órgãos de cunho representativo. (2017, p. 53).

Neste ponto, apesar da mencionada pluralidade de sentidos atribuídos ao termo, há uma ideia predominante nas doutrinas neoconstitucionalistas: admite-se com naturalidade a flexibilização da separação entre os poderes, sob o argumento de que o ativismo judicial deve ser uma faculdade do Poder Judiciário para proteger os "valores constitucionais". Assim, manifesta-se a divergência entre neoconstitucionalismo (principalista) e o constitucionalismo garantista (positivista):

No neoconstitucionalismo, a leitura clássica do princípio da separação de poderes, que impunha limites rígidos à atuação do Poder Judiciário, cede espaço a outras visões mais favoráveis ao ativismo judicial em defesa dos valores constitucionais. No lugar de concepções estritamente majoritárias do princípio democrático, são endossadas teorias de democracia mais substantivas, que legitimam amplas restrições aos poderes do legislador em nome dos direitos fundamentais e da proteção das minorias, e possibilitem a sua fiscalização por juízes não eleitos. E ao invés de uma teoria das fontes do Direito focada no código e na lei formal, enfatizase a centralidade da Constituição no ordenamento, a ubiqüidade da sua influência na ordem jurídica, e o papel criativo da jurisprudência.

Ao reconhecer a força normativa de princípios revestidos de elevada carga axiológica, como dignidade da pessoa humana, igualdade, Estado Democrático de Direito e solidariedade social, o neoconstitucionalismo abre as portas do Direito para o debate moral. É certo que aqui reside uma das maiores divergências internas nas fileiras do neoconstitucionalismo. (SARMENTO, 2009, p. 4).

A crítica do constitucionalismo garantista ao neoconstitucionalismo (principialista) incide precisamente sobre a ampliação desregrada do espaço da jurisdição, invadindo competências do poder legislativo, associada a um conceito de princípios que tende a reduzir o poder normativo da constituição, bem como a uma linguagem legislativa imprecisa, por entender que tais fatores, ao invés de contribuir, deterioram a estabilidade do sistema político e retiram a legitimidade da jurisdição. 
3 CONSTITUCIONALISMO

GARANTISTA

(NORMATIVO)

COMO

ALTERNATIVA

AO

CONSENSO

NEOCONSTITUCIONALISTA (PRINCIPIALISTA)

Embora o constitucionalismo tenha se consolidado a partir das grandes revoluções dos séculos XVII e XVIII, sua gênese não se resume aos movimentos revolucionários liberais ou anti-absolutistas, tais como a Revolução Inglesa, a Independência Americana ou a Revolução Francesa.

O surgimento do constitucionalismo supôs uma alteração na condição jurídica da população com relação ao Estado. Os documentos constitucionais se referem, de várias formas, à existência de uma comunidade definida e organizada politicamente. O Estado já não agrupa os súditos de um soberano, mas sim, organiza uma comunidade que se autodefine como tal. (CRUZ, 2006, p. 45).

Ferrajoli (FERRAJOLI, 2012, p. 13) em capítulo intitulado Constitucionalismo Principialista e Constitucionalismo Garantista, publicado na obra Garantismo, hermenêutica e (neo)constitucionalismo, faz incisivas críticas e propõe uma revisão do termo neoconstitucionalismo. Segundo o autor, apesar de existirem traços que aproximam as diversas concepções de constitucionalismo que surgiram ao longo do século XX - a exemplo da subordinação de todos os poderes públicos aos direitos fundamentais insculpidos nas constituições -, há um traço fundamental que as distingue em pelo menos dois grandes grupos: de um lado estão os defensores de um constitucionalismo como superação em sentido jusnaturalista do positivismo jurídico e, em sentido oposto, há os autores que consideram o constitucionalismo a expansão e o completamento do juspositivismo. A primeira concepção é geralmente associada ao neoconstitucionalismo e é certamente a mais difundida atualmente; por outro lado, o autor denomina a segunda concepção de constitucionalismo positivista ou garantista. A partir desta distinção, posiciona-se expressamente com adepto desta noção de constitucionalismo, ou seja, de uma “concepção de constitucionalismo estritamente juspositivista:

O constitucionalismo rígido, como escrevi inúmeras vezes, não é uma superação, mas sim um reforço do positivismo jurídico, por ele alargado em razão de suas próprias escolhas - os direitos fundamentais estipulados nas normas constitucionais - que devem orientar a produção do direito positivo. Ele é o resultado de uma mudança de paradigma do velho juspositivismo, que se deu com a submissão da própria produção normativa a normas não apenas formais, mas também substanciais, de direito positivo. Representa, portanto, um completamento tanto do positivismo 
jurídico como do Estado de Direito: do positivismo jurídico porque positiva não apenas o "ser", mas também o "dever ser" do direito; e do Estado de Direito porque comporta a submissão, inclusive da atividade legislativa, ao direito e ao controle de constitucionalidade. (FERRAJOLI, 2012, p. 22 e 23).

Antes de prosseguir com a crítica garantista ao neoconstituciolismo, importa salientar que o juspositivismo adotado por Ferrajoli difere drasticamente do chamado positivismo exegético ou paleojuspositivismo. Nas palavras do próprio autor:

O primeiro juspositivismo, aquele do Estado Legislativo de Direito, equivale à positivação do "ser" legal do direito, que permite a democratização das suas formas de produção, condicionando-lhe a validade formal ao seu caráter representativo, sobre o qual se funda a dimensão formal da democracia política. O segundo juspositivismo, aquele do Estado Constitucional de Direito, equivale à positivação do "dever ser" constitucional do próprio direito, que permite a democratização dos seus conteúdos, condicionando-lhe a validade substancial à sua coerência com aqueles direitos de todos, que são os direitos fundamentais, e sobre os quais se funda a dimensão substancial da democracia constitucional. (FERRAJOLI, 2012, p. 22 e 23).

A revisão terminológica do termo neoconstitucionalismo é necessária em razão da pluralidade semântica que o envolve, pertencendo tanto ao léxico político quanto jurídico, isto é, pode designar tanto uma ideologia política ligada à tradição liberal quanto uma teoria do direito ou, ainda, um sistema jurídico:

\footnotetext{
“Em primeiro lugar, a expressão 'constitucionalismo', cujo emprego, para designar uma ideologia, mesmo quando invocada em ordenamentos dotados de sólidas tradições liberal-democráticas, termina por se converter em um termo léxico político ao invés do léxico jurídico, impedindo que se evidencie a transformação do paradigma que intervém na estrutura do direito positivo com a introdução da rigidez constitucional. O mesmo ocorre - e talvez de modo ainda mais intenso - com a expressão "neoconstitucionalismo", porque, ao se referir, sob o plano empírico, ao constitucionalismo jurídico dos ordenamentos dotados de Constituições rígidas, mostra-se assimétrica em relação ao constitucionalismo político e ideológico supraindicado, que não designa um sistema jurídico e tampouco uma teoria do direito, mas serve apenas como Estado Liberal de Direito; e porque, identificada somente sob o plano teórico com a concepção jusnaturalista do constitucionalismo, não assimila as características essenciais e distintivas em relação à sua concepção juspositivista, que lhe resulta, de fato, ignorada. (FERRAJOLI, 2012, p. 15 e 16).
}

Buscando a adoção de uma terminologia homogênea, que evite ambiguidades e seja especificamente relativa à experiência jurídica do constitucionalismo, propõe o autor a utilização dos termos "jus-constitucionalismo", "constitucionalismo jurídico", "Estado Constitucional de Direito" ou ainda simplesmente "constitucionalismo" para designar o constitucionalismo rígido das atuais democracias, independentemente de qual seja sua 


\section{ESTUDO SOBRE O CONSTITUCIONALISMO PRINCIPIALISTA COMO UMA CONTRAPOSIÇÃO AO CONSENSO NEOCONSTITUCIONALISTA}

orientação filosófica ou metodológica. (FERRAJOLI, 2012, p. 17). A partir desta nomenclatura especificamente jurídica, o autor italiano introduz as duas concepções mais atuais do "constitucionalismo jurídico", ao redor das quais orbitam inúmeras teorias do direito: de um lado está o constitucionalismo argumentativo ou principialista e de outro o constitucionalismo positivista ou garantista.

O constitucionalismo principialista ou argumentativo é considerado por seus apologistas como a superação - ou até mesmo como negação - do positivismo jurídico. Podem ser mencionados três aspectos que perpassam as teorias principialistas: a) a tese da conexão entre direito e moral, segundo a qual "a moral, que no velho paradigma juspositivista correspondia a um ponto de vista externo ao direito, agora faria parte do seu ponto de vista interno"; b) "a configuração de uma grande parte das normas constitucionais, a começar pelos direitos fundamentais, não mais como regras suscetíveis de observância ou inobservância, mas sim com princípios que se respeitam em maior ou menor grau [...]”; c) a centralidade da argumentação jurídica, em especial da ponderação, confiada aos juízes. (FERRAJOLI, 2012, p. 20).

O constitucionalismo garantista ou juspositivista, por sua vez, é entendido como completamento “do positivismo jurídico, porque positiva não apenas o 'ser', mas também o 'dever ser' do direito; e do Estado de Direito porque comporta a submissão, inclusive da atividade legislativa ao direito e ao controle de constitucionalidade". Neste contexto, "a legalidade não é mais - como no velho modelo paleopositvista - somente 'condicionante' da validade das normas infralegais, mas é ela mesma 'condicionada', na sua própria validade, ao respeito e à atuação das normas constitucionais" (FERRAJOLI, 2012, p. 23). Entendido desta maneira, o constitucionalismo afasta a poder quase absoluto que esteve associado às maiorias nas democracias representativas liberais, protegendo, assim, as minorias e demais grupos que, mesmo não minoritários, como as mulheres, permanecem politicamente sub-representados.

Para Ferrajoli (FERRAJOLI, 2012, p. 24), há distinção em três significados de constitucionalismo positivista ou garantista: como "modelo ou tipo de sistema jurídico, como teoria do direito e como filosofia política”. Como sistema jurídico o constitucionalismo garantista "configura-se como um sistema de limites e de vínculos impostos pelas Constituições rígidas a todos os poderes e que devem ser garantidos pelo controle jurisdicional de constitucionalidade sobre o seu exercício. Como teoria do direito, é uma teoria que "tematiza a divergência entre o dever ser (constitucional) e o ser (legislativo) do 
direito", ocupa-se prioritariamente da questão do direito constitucionalmente ilegítimo em decorrência de lacunas e antinomias do direito infraconstitucional.

Finalmente, em um terceiro significado, como filosofia política o constitucionalismo garantista consiste em uma teoria da democracia formal e substancial, "ancorada empiricamente no paradigma de direito ora ilustrado. Disso resulta uma teoria da democracia como sistema jurídico e político articulado sobre quatro dimensões correspondentes às garantias de diversas classes de direitos constitucionalmente estabelecidos - os direitos políticos, os direitos civis, os direitos de liberdade e os direitos sociais":

\begin{abstract}
Em suma, o constitucionalismo garantista configura-se como um novo paradigma juspositivista do direito e da democracia que completa - enquanto positivamente normativo nos confrontos da própria normatividade positiva e enquanto sistemas de limites e de vínculos substanciais, relativos ao "que", em acréscimo àqueles somente formais, relativos ao "quem" e ao "como" das decisões - o velho modelo paleo-juspositivista. Graças a ele, os princípios ético-políticos através dos quais eram expressos os velho "direitos naturais" foram positivados, convertendo-se em princípios jurídicos vinculantes nos confrontos de todos os titulares de funções normativas: não mais como fontes de legitimação somente externa ou política, conforme o tradicional pensamento político liberal, mas também como fontes de legitimação e, sobretudo, de deslegitimação interna ou jurídica, que designam a razão social daqueles artifícios que, na verdade, são o Direito e o Estado Constitucional de Direito. Assim a soberania deixa de existir como potestas legibus soluta (poder desvinculado do respeito às leis) por parte de órgãos ou sujeitos institucionais, mesmo que investidos de representação. Ela "pertence ao povo", continuam a afirmar todas as Constituições. Mas esta norma equivale a uma garantia: significa, negativamente, que a soberania pertence ao povo e a nenhum outro e que ninguém - presidente ou assembleia representativa - pode apropriar-se dela e usurpá-la. E, como o povo não é um macrossujeito, mas a soma de milhões de pessoas, a soberania popular é, positivamente, a soma daqueles fragmentos de soberania que são os direitos de todos. (FERRAJOLI, 2012, p. 26).
\end{abstract}

Verifica-se, portanto, uma rejeição ao constitucionalismo principialista ou argumentativo, visto que a as consequências materiais da aplicação de suas teses são prejudiciais ao Estado Constitucional de Direito e à democracia: a conexão entre direito e moral culmina no cognitivismo ético; a diferença qualitativa entre regras e princípios debilita a normatividade da constituição; e a centralidade e liberdade da ponderação no ordenamento jurídico estimula o ativismo judicial, reduzindo a submissão dos juízes à lei. Ou seja, diferentemente do que afirma a doutrina e a jurisprudência no Brasil, o constitucionalismo garantista (ou positivista) é o oposto do neoconstitucionalismo.

\title{
4 DISTINÇÃO QUALITATIVA ENTRE PRINCÍPIOS E REGRAS
}




\title{
ESTUDO SOBRE O CONSTITUCIONALISMO PRINCIPIALISTA COMO UMA CONTRAPOSIÇÃO AO CONSENSO NEOCONSTITUCIONALISTA
}

A fim de compreender a crítica garantista ao constitucionalismo principialista, é imprescindível esclarecer a distinção entre regras e princípios estabelecida por Robert Alexy. Distinção esta que foi amplamente recepcionada pela doutrina e jurisprudência brasileira. Alexy, um dos fundadores e, certamente, um dos mais insignes defensores da corrente principialista, demonstrando a absoluta relevância desta distinção para sua Teoria dos Direitos Fundamentais, afirma que:

\begin{abstract}
Esta distinção é a base da teoria da fundamentação no âmbito dos direitos fundamentais e uma chave para a solução de problemas centrais da dogmática dos direitos fundamentais. Sem ela não pode haver nem uma teoria adequada sobre as restrições a direitos fundamentais, nem uma doutrina satisfatória sobre colisões, nem uma teoria suficiente sobre o papel dos direitos fundamentais no sistema jurídico. Essa distinção constitui um elemento fundamental não somente da dogmática dos direitos de liberdade e de igualdade, mas também dos direitos a proteção, a organização e procedimento e a prestações em sentido estrito. Com sua ajuda, problemas como os efeitos dos direitos fundamentais perante terceiros e a repartição de competências entre tribunal constitucional e parlamento podem ser mais bem esclarecidos. A distinção entre regras e princípios constitui, além disso, a estrutura de uma teoria normativo-material dos direitos fundamentais e, com isso, um ponto de partida para a resposta à pergunta aceca da possibilidade e dos limites da racionalidade no âmbito dos direitos fundamentais. Nesse sentido, a distinção entre regras e princípios é uma das colunas-mestras do edifício da teoria dos direitos fundamentais. (ALEXY, 2017, p. 85). (Grifo nosso).
\end{abstract}

Segundo o autor Alexy, há vários critérios para distinguir regras de princípios, sendo, provavelmente, mais utilizado o da generalidade. Conforme este critério, "princípios são normas com grau de generalidade relativamente alto, enquanto o grau de generalidade das regras é relativamente baixo". Afirma ainda o jusfilósofo alemão que:

\footnotetext{
Outros critérios discutidos são "a determinabilidade dos casos de aplicação", a forma de seu surgimento - por exemplo, por meio da diferenciação entre normas 'criadas' e normas 'desenvolvidas' -, o caráter explícito de seu conteúdo axiológico, a referência à ideia de direito ou uma lei jurídica suprema e a importância para a ordem jurídica. Princípios e regras são diferenciados também com ase no fato de serem razões para regras ou serem eles mesmos regras, ou, ainda, no fato de serem normas de argumentação ou normas de comportamento. (ALEXY, 2017, p. 88 e 89).
}

Em suma, segundo os critérios estabelecidos por Robert Alexy, as normas constitucionais que enunciam valores morais, direitos fundamentais ou objetivos políticos são princípios e não regras. Além disto, as regras se aplicam, enquanto princípios se respeitam e se ponderam, em especial quando há suposto conflito entre princípios. Neste ponto, importa salientar que esta posição, a de considerar princípios e regras qualitativamente distintos, é praticamente consensual na doutrina brasileira, para Barroso:

Revista de Teorias do Direito e Realismo Jurídico | e-ISSN: 2525-9601 | Porto Alegre | v. 4 | n. 2 | p. $107-129$ | Jul/Dez. 2018 
Há consenso na dogmática jurídica contemporânea de que princípios e regras desfrutam igualmente do status de norma jurídica, distinguindo-se uns dos outros por critérios variados, dentro os quais foram destacados no presente estudo os seguintes:

a) Quanto ao conteúdo: regras são relatos objetivos descritivos de condutas a serem seguidas; princípios expressam valores ou fins a serem alcançados;

b) Quanto à estrutura normativa: regras se estruturam, normalmente, no modelo tradicional das normas de conduta: previsão de um fato - atribuição de um efeito jurídico; princípios indicam estados ideais e comportam realização por meio de variadas condutas;

c) Quanto ao modo de aplicação: regras operam por via do enquadramento do fato no relato normativo, com enunciação da consequência jurídica daí resultante, isto é, aplicam-se mediante subsunção; princípios podem entrar em rota de colisão com outros princípios ou encontra resistência por parte da realidade fática, hipóteses em que serão aplicados mediante ponderação. $(2015$, p. 356 e 357).

Ainda com a finalidade de demonstrar a amplitude da aceitação desta tese, é relevante o posicionamento de Canotilho, ilustre constitucionalista português, segundo o qual:

Os princípios interessar-nos-ão, aqui, sobretudo na sua qualidade de verdadeiras normas, qualitativamente distintas das outras categorias de normas, ou seja, das regras jurídicas. As diferenças qualitativas traduzir-se-ão, fundamentalmente, nos seguintes aspectos. Os princípios são normas jurídicas impositivas de uma optimização, compatíveis com vários graus de concretização, consoantes os condicionalismos fácticos e jurídicos; as regras são normas que prescrevem imperativamente uma exigência (impõem, permitem ou proíbem) que é ou não é cumprida (nos termos de Dworkin: aplicable in all-or-nothing fashion); a convivência dos princípios é conflitual (Zagrebelsky), a convivência das regras é antinómica; os princípios coexistem, as regras antinómicas excluem-se. Consequentemente, os princípios, ao constituírem exigências de optimização, permitem o balanceamento de valores e interesses (não obedecem, como regras, à 'lógica do tudo ou nada'), consoante o seu peso e a ponderação de outros princípios eventualmente conflituantes; as regras não deixam espaço para qualquer outra solução, pois se uma regra vale (tem validade) deve cumprir-se na exacta medida das suas prescrições, nem mais nem menos. Como se verá mais adiante, em caso de conflito entre princípios, estes podem ser objecto de ponderação e de harmonização, pois eles contêm apenas 'exigências' ou 'standards' que em 'primeira linha' (prima facie), devem ser realizados; as regras contêm 'fixações normativas' definitivas, sendo insustentável a validade simultânea de regras contraditórias. Realça-se também que os princípios suscitam problemas de validade e peso (importância, ponderação, valia); as regras colocam apenas questões de validade (se elas não são correctas devem ser alteradas). (2003, p. 1161 e 1162).

Após esta necessária explanação, a crítica garantista (positivista) ao constitucionalismo principialista (argumentativo) certamente será mais compreensível, posto que esta incide, sobretudo sobre a distinção estrutural e qualitativa entre regras e princípios, bem como sobre a consequente ampliação do espaço de discricionariedade de legisladores e julgadores, uma vez que a ponderação, diversamente da subsunção, não vincula a atuação de legisladores e aplicadores das normas jurídicas, o que reduz a segurança jurídica dos cidadãos jurisdicionados.

Revista de Teorias do Direito e Realismo Jurídico | e-ISSN: 2525-9601 | Porto Alegre | v. 4 | n. 2 | p. 107 - 129 | Jul/Dez. 2018 


\section{CRÍTICA GARANTISTA AO CONSTITUCIONALISMO PRINCIPIALISTA}

O ponto fulcral da crítica do constitucionalismo garantista à distinção qualitativa entre regras e princípios é o "radical enfraquecimento do valor vinculante de todos os princípios, sobretudo, se de nível constitucional” (FERRAJOLI, 2012, p. 41). Inicialmente, importa salientar que o autor não ignora o fato de que existem princípios que enunciam valores de caráter político, dos quais não é simples identificar a observância ou inobservância. Estes são denominados princípios diretivos. Tratam-se, no entanto, de princípios marginais e minoritários, caracterizados como expectativas genéricas e indeterminadas, não de atos, mas de resultados.

Por outro lado, há os princípios reguladores ou imperativos, que "exprimem expectativas específicas e determinadas, às quais correspondem limites ou vínculos, isto é, garantias consistentes nas relativas proibições de lesão e obrigação de prestação" (FERRAJOLI, 2012, p. 38). Os princípios reguladores ou imperativos são a maioria dos princípios constitucionais, a exemplo dos princípios de igualdade e liberdade, cuja inobservância é materialmente possível, mas juridicamente proibida.

Neste sentido, os princípios diferem das regras por serem formulados de maneira diversa, isto é, enquanto as "regras se estruturam, normalmente, no modelo tradicional das normas de conduta: previsão de um fato - atribuição de um efeito jurídico" (BARROSO, 2015, p. 356), os princípios são formulados "com base no seu respeito, e não na sua violação, e, consequente, aplicação, como ocorre nas regras":

Uma prova disso é que mesmo as regras, inclusive aquelas penais, às quais se exige a máxima taxatividade, quando são observadas exsurgem como princípios que não se aplica, mas se respeitam: por exemplo, a observância das normas sobre o homicídio ou sobre lesões corporais ou sobre o furto equivale ao respeito dos princípios da vida, da integridade corporal e da propriedade privada. É possível afirmar que por trás de cada regra existe um princípio: até mesmo atrás da proibição de estacionar os veículos ou, ainda, atrás da obrigação de parar quando o semáforo está vermelho, há princípios, como aqueles da segurança e da mais eficiente e racional circulação nas estradas. Inversamente, também os princípios reguladores, quando são violados, aparecem como regras, que não se respeitam, mas se aplicam: por exemplo, o princípio constitucional da igualdade, quando é violado, surge como regra em relação às suas violações: a regra, precisamente, que proíbe as discriminações. (FERRAJOI, 2012, p. 39).

A diferença entre regras e princípios, sob a ótica garantista, é, portanto, mais uma questão formal ou de estilo do que substancial, estrutural e qualitativa. 
O autor define a Constituição, "na sua parte substancial, não só como um conjunto de direito fundamentais das pessoas, isto é, de princípios, mas também como um sistema de limites e de vínculos, isto é, de regras destinadas aos titulares dos poderes" (FERRAJOLI, 2017, p. 90). A equiparação entre princípios e regras objetiva expressamente fortalecer o caráter vinculante das constituições, reduzindo a esfera de discricionariedade de legisladores e juízes, pois somente desta maneira os cidadãos poderão estar seguros contra eventuais abusos de poder e exigir a concretização de suas garantias.

Ao afirmar que os princípios são meros "mandamentos de otimização, que são caracterizados por poderem ser satisfeitos em graus variados" (ALEXY, 2017, p. 90), a tese principialista acaba por legitimar lacunas e antinomias na produção legislativa e o ativismo judicial, uma vez que os membros do Poder Legislativo e Judiciário não estariam vinculados e limitados pelas normas constitucionais expressas em forma de princípios. As consequências práticas deste enfraquecimento do valor vinculante da Constituição são facilmente verificáveis no ordenamento jurídico brasileiro: por um lado, após 29 (vinte e nove) anos da promulgação da Constituição Federal de 1988, ainda há centenas de dispositivos constitucionais não regulamentados, impedindo que povo possa usufruir de seus direitos e garantias constitucionais; por outro lado, a tese de que a Constituição não é rigidamente vinculante, mas, em grande medida, mera exposição de princípios ético-políticos, orientou a trajetória doutrinária e jurisprudencial pátria no sentido da criação princípios sem qualquer fundamento na constituição. Analisando a ampla recepção das teses principialistas pela doutrina e jurisprudência pátria, Streck (2012, p. 67) afirma que estamos diante de um fenômeno que pode ser chamado de "pan-principiologismo:

Veja-se nesse sentido, parte do incontável (e incontrolável) elenco de "princípios" utilizados largamente na cotidianidade dos tribunais e da doutrina - a maioria deles com nítida pretensão retórico-corretiva, além da tautologia que os conforma. Podem ser citados o princípio da simetria (menos um princípio de validade geral e mais um mecanismo ad hoc de resolução de controvérsias que tratam da discussão de competências), princípio da precaução (por que a "precaução" - que poderíamos derivar da velha prudência - seria um princípio?); princípio da não surpresa (não passa de um enunciado com pretensões performativas, sem qualquer normatividade); princípio da afetividade: (esse prêt-à-portêr nada mais faz do que escancarar a compreensão do direito como subsidiário de juízos morais; daí a perplexidade: se os princípios constitucionais são deontológicos, como retirar da "afetividade" essa dimensão normativa?); princípio do fato consumado (fosse válido esse "princípio", estaríamos diante de um incentivo ao não cumprimento das leis, apostando na passagem do tempo ou na ineficiência da justiça); princípio da cooperação processual (em que condições um standard desse quilate pode ser efetivamente 
aplicado? Há sanções no caso de "não cooperação"? qual será a ilegalidade ou inconstitucionalidade decorrente de sua não aplicação?); princípio da confiança no juiz da causa (serve para justificar qualquer decisão: para prender e para soltar; princípio da humanidade (esse standard dispensa comentários); princípio da situação excepcional consolidada (está no Top Five do pan-principiologismo que assola o direito de terrae brasilis; cabe a pergunta: um fato consumado supera uma prescrição normativa? Quem vai eleger as circunstâncias excepcionais? O Judiciário? Pensando-se num caráter de "universalização do princípio" ou na sua importância hermenêutica, surge, ainda, a seguinte indagação: quando se poderia reconhecer a normatividade da situação excepcional consolidada? Não poderia ela sempre ser reconhecida quando se pretende uma desoneração da força normativa da Constituição?); princípio da felicidade (neste ponto o direito brasileiro se torna insuperável; por esse standard, a Constituição "garante" o direito de todos serem felizes...). (STRECK, 2012, p. 65 e 66).

Para o autor o que vem ocorrendo é uma formulação de uma variedade de álibis teóricos denominados "princípios", os quais certamente são importantes na busca por soluções jurídicas na prática judiciária, mas que, na maioria dos casos, "possuem nítidas pretensões de meta-regras, além de, em muitos casos, sofrerem de tautologia”. Neste cenário “pan-principiologista”, em caso de "'ausência' de 'leis apropriadas' (a aferição é desse nível de adequação é feita, evidentemente, pelo protagonismo judicial), o intérprete 'deve' lançar mão dessa ampla principiologia, sendo que na falta de um 'princípio' aplicável, o próprio intérprete pode criá-lo" (STRECK, 2012, p. 67). Assim, evidencia-se a diminuição dos vínculos e limites impostos pelas normas constitucionais ao julgador, afinal incumbe-lhes aferir, mediante ponderação e não subsunção, qual princípio (e com que peso) deve ser aplicado ao caso concreto. Bem como pode livremente usar de sua criatividade para conceber supostos princípios que orientarão sua decisão, mesmo sem fundamento constitucional.

A identificação da ponderação como única racionalidade concernente aos princípios, em oposição à subsunção na aplicação das regras, tem como consequência o enfraquecimento do aspecto vinculante das normas constitucionais e do caráter cognitivo da jurisdição, além da ampliação do ativismo e discricionariedade na atividade jurisdicional. Ferrajoli afirma que “entramos, como se diz, na 'era da ponderação', havendo sido descoberto um novo tipo de racionalidade jurídica, reservado, entretanto, aos direitos fundamentais, bem mais do que às outras normas do ordenamento" (FERRAJOLI, 2012, P. 46).

Evidentemente, o constitucionalismo garantista não pretende afastar completamente a ponderação e argumentação da atividade judicial. Haverá sempre espaço para a ponderação legislativa, atividade inerente às esferas de decisão política, desde que ocorra dentro das balizas constitucionais; bem como para a interpretação jurídica, atividade reconhecidamente 
intrínseca à atividade judicial. A ponderação, no entanto, não deve extrapolar os constitucionalmente delineados:

\begin{abstract}
Os espaços de discricionariedade da jurisdição, de fato, são inegáveis. Até mesmo em matéria penal, onde é máximo o valor da certeza, podem se distinguir, facilmente, três espaços fisiológicos e insuprimíveis de discricionariedade judiciária que correspondem, entre tantos, aos seguintes tipos de poder: o poder de qualificação jurídica, que corresponde aos espaços de interpretação da lei, ligados à semântica da linguagem legal; o poder de verificação factual ou de valoração das provas, que corresponde aos espaços da ponderação dos indícios e dos elementos probatórios; o poder equitativo de conotação dos fatos verificados, que corresponde aos espaços da compreensão e ponderação dos conotados singulares e irrepetíveis de cada fato, mesmo se todos igualmente subsumíveis na mesma figura legal do crime. Estes espaços podem ser fortemente reduzidos, mas não suprimidos pelo conjunto das garantias penais e processuais: daqui, a importância de uma adequada teoria da argumentação em condição de orientar, racionalmente a motivação das decisões tomadas no exercício dos três poderes a eles correspondentes. (FERRAJOLI, 2012, p. 46 e 47$)$.
\end{abstract}

Apesar da constatação supra, sustenta Ferrajoli (FERRAJOLI, 2012, p. 38 e 47) que vem ocorrendo uma ampliação desmedida do papel da ponderação na atuação legislativa e na interpretação jurisdicional. Considera que "por causa de tal ampliação, a ponderação terminou se transformando, nestes últimos anos, em uma espécie de bolha terminológica, tão dilatada que chegou às formas mais variadas de esvaziamento e de inaplicação das normas constitucionais, tanto do nível legislativo quanto no nível jurisdicional”. Quanto à ponderação legislativa retoma os conceitos anteriormente mencionados de princípios diretivos (caracterizados "como expectativas genéricas e indeterminadas, não de atos, mas de resultados" e princípios reguladores (que "exprimem expectativas específicas e determinadas, às quais correspondem limites ou vínculos, isto é, garantias consistentes nas relativas proibições de lesão e obrigação de prestação".

A partir desta distinção, afirma o autor que a ponderação legislativa "é exigida para os princípios diretivos, mas não o é para os princípios reguladores, vinculantes e infalíveis quando não encontram limites formulados mediante princípios diretivos”. Relevante salientar que sob esta ótica, a regulamentação dos direitos sociais - a exemplo dos direitos à educação, à saúde, à alimentação, ao trabalho, dentre outros - encontra-se em posição intermediária nesta classificação, uma vez que os princípios que afirmam tais direitos são reguladores quanto ao "se", e diretivos quanto ao "como" e ao "quanto" de sua atuação. 


\title{
ESTUDO SOBRE O CONSTITUCIONALISMO PRINCIPIALISTA COMO UMA CONTRAPOSIÇÃO AO CONSENSO NEOCONSTITUCIONALISTA
}

Por conseguinte, a atuação do legislador é vinculada no aspecto da produção da norma, isto é, tem o dever de legislar, e, por outro lado, admite a ponderação, dentro dos limites constitucionais, quanto à forma pela qual os direitos serão regulamentados.

\begin{abstract}
A falta de regulamentação equivale, portanto, à sua violação, que resulta em lacunas não menos ilegítimas do que as antinomias. Mas é claro que uma ponderação legislativa é fisiológica nas escolhas legislativas, inevitavelmente discricionárias em relação aos meios, às formas e também aso limites de sua atuação, que não são predeterminados pela sua formulação constitucional. A ponderação, em outras palavras, não pode se estender à escolha de quais princípios constitucionais devem atuar e quais não devem atuar, sem resultar num descumprimento da Constituição e, portanto, na admissão de um poder do legislador, em contraste com a hierarquia das fontes, de tornar inútil ou, de qualquer modo, de derrogar o preceito constitucional: um poder que, como se viu, a tese da falibilidade das normas constitucionais, serve para legitimar, uma vez que configura como inevitáveis, porque consequentes às ponderações, as violações e os descumprimentos delas em benefício da atuação de outras. (FERRAJOLI, 2012, p. 47 e 48).
\end{abstract}

Por este prisma, é infundado o argumento segundo o qual a garantia de um direito fundamental comporta prejuízo à concretização de outro, o que tornaria necessária a ponderação legislativa dos direitos em conflito. "as relações entre os direitos, como a experiências histórica nos ensina, são, sobretudo, de sinergia” Ferrajoli (FERRAJOLI, 2012, p. 48), ou seja, na realidade há diversos direitos fundamentais que somente podem ser concretizados mediante a garantia de outros, por exemplo: os direitos políticos e a soberania popular somente poderão ser exercidos mediante a prévia garantia dos direitos sociais à educação e saúde.

Quanto à ponderação no exercício da atividade jurisdicional, o autor entende que o termo se aproxima da "intepretação sistemática", ou seja, a intepretação de uma norma a partir de sua relação com o conjunto normativo em que está inserido, evitando eventuais incoerências entre norma (regra ou princípio) e o restante do sistema jurídico. No entanto, considera haver uma importante diferença que expande os limites da ponderação ao ponto de ameaçar a subordinação do juiz à lei:

Tal diferença está ligada à metáfora do "peso", que sugere e favorece - em singular contraste com a ideia dworkiana da objetiva existência de "somente uma resposta correta" - um Poder Judiciário de escolha em relação a quais princípios aplicar e quais não aplicar sobre a base da valoração, inevitavelmente discricionária, a partir de sua diversa importância. A ponderação resulta, assim, identificada com uma operação através da qual, como escreve Robert Alexy, "quando dois princípios entram em conflito [...] um dos dois deve ceder ao outro", sem que o primeiro seja considerado "invalido" ou o segundo prevalecente com base no principio da 
especialidade. É concebida, em suma, com uma atividade de escolha "orientada" pela "exigência de justiça substancial", que arrisca comprometer não apenas a submissão do juiz à lei, mas também, como observou justamente Riccardo Guastini, os valores da certeza e da igualdade perante a lei. (FERRAJOLI, 2012, p. 49).

O constitucionalismo garantista ou jus-positivista não acolhe a tese da diferença qualitativa entre regras e princípios e, consequentemente, tampouco acolhe a metáfora do "peso". Nesta perspectiva, os juízes não ponderam as normas, sejam regras ou princípios, mas as cumprem; o objeto de ponderação, portanto, não são as normas, que são sempre as mesmas e possuem o mesmo "peso", mas sim as circunstâncias concretas que demandam sua aplicação.

Conforme já mencionado, o constitucionalismo garantista não propõe a exclusão absoluta da ponderação judicial, mas sim a sua restrição a níveis mínimos e a âmbitos específicos da atividade do julgador. A indeterminação semântica e potencial ambiguidade de determinados conceitos jurídicos exigem, inevitavelmente, a interpretação jurídica para sua aplicação. Argumenta-se, na realidade, que os princípios têm o condão de reduzir tais espaços de discricionariedade, substituindo opções ético-políticas e valores individuais do julgador, por intepretações vinculadas à orientação principológica, ou seja, "de todas as possíveis interpretações admitidas para um mesmo texto, são escolhidas como válidas somente aquelas compatíveis com a Constituição" Ferrajoli (FERRAJOLI, 2012, p. 51). Além desta "condução coercitiva" da interpretação judicial pelos princípios, "seria oportuno que a cultura jusconstitucionalista - em vez de assumir como inevitáveis a indeterminação da linguagem constitucional e os conflitos entre os direitos e, provavelmente, preferir um ao outro, com base no ativismo judicial - promovesse o desenvolvimento de uma linguagem legislativa e constitucional o mais precisa e rigorosa possível”. Logo, não se deve aceitar a imprecisão e ambiguidade como características intrínsecas à linguagem jurídica; as quais, aliás, configuram um vício jurídico que corrobora para a violação da separação dos poderes e afrouxa a submissão dos juízes à lei.

Busca-se extirpar da prática jurídica o que o autor denomina de "poder de disposição", isto é, um "poder criativo, que não pode ser reconduzido aos três poderes fisiológicos - de interpretação das leis, de valoração das provas e de conotação equitativa dos fatos -“, o qual representa ofensa à separação dos Poderes, uma vez que invade a competência 


\title{
ESTUDO SOBRE O CONSTITUCIONALISMO PRINCIPIALISTA COMO UMA CONTRAPOSIÇÃO AO CONSENSO NEOCONSTITUCIONALISTA
}

do Poder Legislativo, e, consequentemente, coloca em risco a estabilidade do Estado Constitucional de Direito.

Em apertada síntese, o insigne doutrinador italiano define da seguinte forma a crítica garantista ao constitucionalismo principialista (ou não positivista):

\begin{abstract}
Em suma, bem mais do que no modelo principialista e argumentativo - que confia a solução as aporias e dos conflitos entre direitos à ponderação judicial, enfraquecendo, assim, a normatividade das Constituições e a fonte de legitimação da jurisdição -, o paradigma garantista do constitucionalismo rígido exige que o Poder Judiciário seja o mais limitado e vinculado possível pela lei e pela Constituição, conforme o princípios da separação dos poderes e a natureza quanto mais legítima mais cognitiva - e não discricionária - da jurisdição. Os juízes, com base neste paradigma, não ponderam normas, mas sim as circunstâncias fáticas que justificam ou não a sua aplicação. Eles não podem criar e nem ignorar normas, o que implicaria uma invasão no campo da legislação, mas somente censurar a sua invalidade por violação á Constituição, anulando-as no âmbito da jurisdição constitucional, ou, então, suscitando exceções de inconstitucionalidade no âmbito da jurisdição ordinária; em ambos os casos, intervindo, assim, não na esfera legitima, mas na esfera ilegítima da política. Na verdade, a legitimidade da jurisdição se funda, a meu ver, sobre o caráter mais cognitivo possível da subsunção e da aplicação da lei, dependente por sua vez - bem mais do que pela formulação como regra - do grau de taxatividade e de determinação da linguagem legal; enquanto a indeterminação normativa e a consequente discricionariedade judicial são sempre um fator de deslegitimação da atividade do juiz. Sob este aspecto, o cognitivismo judicial (veritas non auctoritas facit iudicium), mesmo como ideal regulador é a outra face do convencionalismo legal, isto é do princípio juspositivista da legalidade (auctoritas non veritas facit legem). É óbvio que a satisfação de um ideal semelhante é uma questão de grau, dependente do nível da determinação ou da estreita legalidade da linguagem legal. Mas, ao ultrapassar certo grau de indeterminação, quando se converte em poder criativo ou de disposição, o Poder Judiciário - repito perde qualquer legitimidade. E isto pode ocorrer seja quando as normas forem expressas em forma de princípios, seja quando forem expressas em forma de regras. (FERRAJOLI, 2012, p. 46 et all).
\end{abstract}

Conforme o exposto, segundo o constitucionalismo garantista, as premissas fundamentais do constitucionalismo principialista (identificação do direito à moral, distinção estrutural e qualitativa entre princípios e regras e o protagonismo da ponderação) tendem a enfraquecer a normatividade dos princípios e, consequentemente, da própria Constituição, além de convulsionar a hierarquia das fontes, conferindo à discricionariedade de legisladores e juízes a faculdade de decidir, mediante ponderação orientada por valores ético-políticos, quais princípios constitucionais deverão ser regulamentados e aplicados aos casos concretos. Neste cenário, doutrina e jurisprudência ocupariam a posição de fonte suprema do direito, desprezando a positivação do "dever ser" e a submissão de todos a limites e vínculos constitucionais, o que, em última análise, representa o retorno a um direito jurisprudencial pré-moderno e superado.

Revista de Teorias do Direito e Realismo Jurídico | e-ISSN: 2525-9601 | Porto Alegre | v. 4 | n. 2 | p. 107 - 129 | Jul/Dez. 2018 
Ao contrário, o constitucionalismo juspositivista e garantista, teorizando o desnível normativo e a resultante divergência entre normas constitucionais sobre a produção e normas legislativas produzidas, impõe reconhecer, como sua virtual e fisiológica consequência, o direito ilegítimo, inválido por comissão ou descumprido por omissão, porque violam o seu "dever ser jurídico". E, portanto, confere à ciência jurídica um papel crítico nos confrontos do próprio direito: das antinomias, geradas pela indevida presença de normas em contraste com os princípios constitucionais; e das lacunas, geradas pela indevida falta de normas por eles implicadas e impostas. Comporta, em síntese o reconhecimento de uma normatividade forte das constituições rígidas, em razão da qual, estabelecido constitucionalmente um direito fundamental, se a Constituição é levada a sério, não devem existir normas com ele em contradição e deve existir - no sentido de que deve ser encontrado através da interpretação sistemática, ou deve ser introduzido mediante legislação ordinária - o dever a ele correspondente, que compete à esfera pública. Trata-se de uma normatividade forte nos confrontos, em via primária, da legislação à qual se impõe evitar as antinomias e colmatar as lacunas através de leis idôneas de regulamentação; e, em via secundária, da jurisdição à qual se impõe remover as antinomias e apontar as lacunas Ferrajoli. (FERRAJOLI, 2012, p. 56).

\title{
6 ATIVISMO JUDICIAL NO BRASIL
}

Antes de prosseguir a análise do fenômeno do ativismo judicial no Brasil, importa distinguir ativismo judicial de judicialização da política. Segundo Lenio Luiz Streck:

\begin{abstract}
Assim, é preciso diferenciar o ativismo judicial da judicialização da política, questão que no Brasil foi examinada com pouca profundidade, como se os fenômenos tratassem da mesma coisa. Essa dificuldade conceitual deve ser enfrentada, especialmente porque vivemos sob um regime democrático, cujas consequências do ativismo podem ser muito prejudiciais. É nesse sentido que é possível afirmar que a judicialização da política é um fenômeno, ao mesmo tempo inexorável e contingencial, porque decorre de condições sociopolíticas, bem como consiste na intervenção do Judiciário nas deficiências dos demais Poderes. Por outro lado, o ativismo é gestado no interior da própria sistemática jurídica, consistindo num ato de vontade daquele que julga, isto é, caracterizando uma "corrupção" na relação entre os Poderes, na medida em que há uma extrapolação dos limites na atuação do judiciário pela via de uma decisão que é tomada a partir de critérios não jurídicos. (STRECK, 2012, p. 87).
\end{abstract}

Após circunscrever o fenômeno que se pretende analisar, qual seja o ativismo judicial, pode-se prosseguir com mais clareza. Os infindáveis escândalos de corrupção envolvendo praticamente todos os partidos políticos do país, paulatinamente minaram a confiança da população na política e, consequentemente, favoreceram a expansão o ativismo judicial no Brasil. Luís Roberto Barroso pontua que o ativismo judicial normalmente "se instala - e este é o caso do Brasil - em situações de retração do Poder Legislativo, de um certo descolamento entre a classe política e a sociedade civil, impedido que determinadas

Revista de Teorias do Direito e Realismo Jurídico | e-ISSN: 2525-9601 | Porto Alegre | v. 4 | n. 2

p. $107-129$ | Jul/Dez. 2018 


\section{ESTUDO SOBRE O CONSTITUCIONALISMO PRINCIPIALISTA COMO UMA CONTRAPOSIÇÃO AO CONSENSO NEOCONSTITUCIONALISTA}

demandas sociais sejam atendidas de maneira efetiva”. Salienta-se que, apesar de todas as objeções expostas até aqui, importante parte da doutrina e jurisprudência pátria vê com bons olhos o surgimento e o desenvolvimento do ativismo judicial no país, tanto é assim que, segundo Barroso, "a ideia de ativismo judicial está associada a uma participação mais ampla e intensa do judiciário na concretização dos valores e fins constitucionais, com maior interferência no espaço de atuação dos outros dois Poderes”. (BARROSO, 2015, p. 441 e 442).

A partir de sua visão positiva do ativismo judicial no Brasil, expande os limites da ponderação, afirmando que em uma nova hermenêutica constitucional, este método deve ser aplicado não somente aos princípios, mas também às regras:

\footnotetext{
Princípios - e, com crescente adesão na doutrina, também as regras - são ponderados, à vista do caso concreto. E, na determinação de seu sentido e na escolha dos comportamentos que realizarão os fins previstos, deverá o intérprete demonstrar o fundamento racional que legitima sua atuação. (BARROSO, 2015, p. 38).

A ponderação de valores, interesses, bens ou normas consiste em uma técnica de decisão jurídica utilizável nos casos difíceis, que envolvem a aplicação de princípios (ou, excepcionalmente, de regras) que se encontram em linha de colisão, apontando soluções diversas e contraditórias para a questão. O raciocínio ponderativo, que ainda busca parâmetros de maior objetividade, inclui a seleção das normas e dos fatos relevantes, com a atribuição de pesos aos diversos elementos em disputa, em um mecanismo de concessões recíprocas que procura preservar, na maior intensidade possível, os valores contrapostos. (BARROSO, 2015, p. 64).
}

Em outro giro, a crítica do constitucionalismo garantista ao constitucionalis mo principialista, identificado em grande medida com o neoconstitucionalismo, lança luz sobre os riscos da interiorização de suas teses à prática jurídica sem a devida reflexão. O surgimento e rápida propagação, pouco questionada e insuficientemente estudada, de posturas ativistas entre os membros do Poder Judiciário brasileiro é corolário da difusão das teses principialistas associadas à mencionada crise política brasileira. André Karam Trindade, em expresso contraponto à postura de Luís Roberto Barroso, afirma que:

Ocorre que, ao contrário da leitura otimista sugerida por Barroso - segundo a qual o ativismo é uma tendência mundial, na esteira do constitucionalismo, em face da fluidez da fronteira entre politica e direito -, o ativismo judicial torna-se um fenômeno muito mais complexo e perigoso, especialmente às jovens democracias constitucionais, quando entendido com a recusa dos tribunais de sem manterem dentro dos limites constitucionais estabelecidos para o exercício do perder a eles atribuídos pela Constituição. (TRINDADE, 2015, p.116). 
A distinção qualitativa e estrutural entre princípios e regras abre portas para o surgimento do ativismo judicial, pois, ao defender que os princípios não devem ser aplicados mediante subsunção, mas sim objeto de ponderação em cada caso concreto, ocasiões nas quais o julgador deve optar por um (ou alguns) princípio(s) em detrimento de outros, esta tese reduz o poder normativo e vinculante do ordenamento jurídico e, consequentemente amplia o excessivamente o espaço de discricionariedade dos juízes. Trata-se de um vício do sistema jurídico-político, consistente "na recusa dos tribunais de se manterem dentro dos limites jurisdicionais estabelecidos para o exercício do poder a eles atribuídos pela Constituição". (TRINDADE, 2015, p. 111).

Este vício agrava-se na medida em que, ao defrontar-se com os denominados hard cases (os quais somente podem ser solucionados mediante a ponderação de princípios, em oposição aos easy cases, resolvidos mediante subsunção), parte considerável da doutrina e da jurisprudência julga ser cabível a formulação de princípios para deslindar casos concretos, ainda que sem fundamentação constitucional, uma vez que os princípios seriam a:

"positivação de valores": assim se costuma anunciar os princípios constitucionais,
circunstância que facilita a "criação" (sic), em um segundo momento, de todo tipo
de "princípio" (sic), como se o paradigma do Estado Democrático de Direito fosse a
"pedra filosofal da legitimidade principiológica", da qual pudessem ser retirados
tantos princípios quantos necessários para resolver os casos dificeis ou "corrigir"
as incertezas da linguagem. (STRECK, 2012, p.65). (Grifo nosso).

Como alternativa ao paradigma principialista, o constitucionalismo garantista defende a normatividade dos princípios constitucionais, contrapondo-se à ponderação. Esta normatividade fundamenta-se na ideia de que regras e princípios não são qualitativamente distintos, refutando a tese de Robert Alexy, segundo a qual os princípios são meros "mandamentos de otimização, que são caracterizados por poderem ser satisfeitos em graus variados", enquanto as regras devem ser plenamente cumpridas, ou seja, "se uma regra vale, então, deve se fazer exatamente aquilo que ela exige" (ALEXY, 2017, p. 90 e 91). A distinção, segundo Ferrajoli é uma diferença de estilo, pois os princípios são formulados "com base no seu respeito, e não na sua violação e, consequentemente, aplicação, como ocorre nas regras" (FERRAJOLI, 2012, p. 38 e 39). A normatividade dos chamados "princípios reguladores" é, portanto, idêntica a das regras, vinculando e limitando a atuação dos juízes. Propõe ainda o desenvolvimento de uma "linguagem legislativa e constitucional o mais 
precisa e rigorosa possível", pois a indeterminação semântica das normas, associada à desconsideração da normatividade dos princípios constitucionais, atribui aos julgadores o ilegítimo "poder de disposição". (FERRAJOLI, 2012, p. 51 e 54).

A insubordinação dos juízes à lei, bem com a indiscriminada liberdade de formulação de princípios, além de inviabilizar a concretização dos direitos e garantias constitucionais, colocam em perigo a própria independência e segurança da jurisdição:

Se, na verdade, sustenta-se que os juízes não devem se limitar a interpretar as normas de direito positivo, mas estão habilitados eles mesmos, a criá-las - ainda que através da ponderação dos princípios -, então resulta violada a separação dos Poderes. E, em tempos como os atuais - de crescente tensão entre o poder político e o Poder Judiciário e de intolerância do primeiro com os controles de legalidade exercidos pelo segundo -, a teorização deste poder normativo dos juízes arrisca propiciar um potente argumento em favor de sua investidura política, por meio de eleição, ou pior, a sua colocação de dependente do Poder Executivo. (FERRAJOLI, 2012, p. 45 e 46).

Em síntese, o constitucionalismo garantista objetiva minguar o ativismo judicial, manter a legitimidade da jurisdição, bem como evitar instabilidades na separação entre os Poderes e, consequente, riscos ao Estado Constitucional de Direito e à democracia.

\section{CONCLUSÃO}

Após percorrer todo o trajeto deste estudo, passando pelas definições de neoconstitucionalismo (principialista), constitucionalismo garantista (positivista) e normas (regras e princípios); transitando pelas principais críticas feitas pela teoria garantista ao constitucionalismo principialista, bem como as possíveis consequências negativas de sua aplicação precipitada e irrefletida; e, finalmente, arrematando com a análise o ativismo judicial decorrente da recepção do principialismo pela doutrina e jurisprudência pátria, o leitor certamente verificou que foi exposto a um ponto de vista alternativo ao atual consenso neoconstitucionalista predominante no Brasil. Conforme estabelecido na introdução, este é precisamente o objetivo deste estudo, qual seja singelamente contribuir com o debate, levantando questionamentos e procurando trazer novos elementos para a compreensão do fenômeno do constitucionalismo no país.

A atual crise política que assola o país, com desdobramentos em todas as esferas da vida em sociedade, tem causado desequilíbrios e atritos entre os poderes. Neste cenário, a atribuição de uma normatividade "forte" à constituição deve ser considerada uma das 
possíveis alternativas para solução dos dilemas que cotidianamente colocam os Poderes da República em polos opostos na disputa pelo protagonismo no lento e complexo processo de restauração do prestígio do Estado Constitucional de Direito perante o povo brasileiro. Isto é, a solução dos problemas nacionais não deve passar pela subjetividade de legisladores ou julgadores, mas deve ser encontrada dentro do ordenamento constitucional, mediante sua adequada interpretação e estrito cumprimento.

\section{REFERÊNCIAS}

ALEXY, Robert. Teoria dos Direitos Fundamentais. Tradução de Virgílio Afonso da Silva. 2. Ed. São Paulo: Malheiros Editores, 2017.

BARroso, Luís Roberto. Curso de Direito Constitucional Contemporâneo. 5. ed. São Paulo: Saraiva, 2015.

BARROSO, Luís Roberto; BARCELLOS, Ana Paula de. O começo da história. A nova interpretação constitucional e o papel dos princípios do direito brasileiro. In. Revista da Escola da Magistratura do Estado do Rio de Janeiro. vol. 6. n. 23. Rio de Janeiro. 2003.

BRANCO, Paulo Gustavo Gonet; MENDES, Gilmar Ferreira. Curso de Direito Constitucional. 12. ed. São Paulo: Saraiva, 2017.

CANOTILHO, José Joaquim Gomes. Direito constitucional e teoria da constituiçãa. 7. ed. Coimbra: Almedina, 2003.

FERRAJOLI, Luigi. Constitucionalismo principialista e constitucionalismo garantista. In. Garantismo, hermenêutica e (neo)constitucionalismo: um debate com Luigi Ferrajoli. Porto Alegre: Livraria do Advogado, 2012.

FERRAJOLI, Luigi. O constitucionalismo garantista e o estado de direito. In. Garantismo, hermenêutica e (neo)constitucionalismo: um debate com Luigi Ferrajoli. Porto Alegre: Livraria do Advogado, 2012.

SARMENTO, Daniel. Neoconstitucionalismo no Brasil: risco e possibilidades. 2009. Disponível em: <http://www.dsarmento.adv.br/content/3-publicacoes/15-oneoconstitucionalismo-no-brasil-riscos-e-possibilidades/o-neoconstitucionalismo-nobrasil.riscos-e-possibilidades-daniel-sarmento.pdf>. Acesso em: 10 de nov. 2017.

STRECK, Lenio Luiz. Neoconstitucionalismo, positivismo e pós-positivismo. In. Garantismo, hermenêutica e (neo)constitucionalismo: um debate com Luigi Ferrajoli. Porto Alegre: Livraria do Advogado, 2012.

STRECK, Lenio Luiz. Verdade e Consenso. Constituição, hermenêutica e teorias discursivas. 6. ed. São Paulo: Saraiva, 2017.

Revista de Teorias do Direito e Realismo Jurídico | e-ISSN: 2525-9601 | Porto Alegre | v. 4 | n. 2 |

p. 107 - 129 | Jul/Dez. 2018 
TRINDADE, André Karam. Garantismo versus neconstitucionalismo: os desafios do protagonismo judicial em terrae brasilis. In. Garantismo, hermenêutica e (neo)constitucionalismo: um debate com Luigi Ferrajoli. Porto Alegre: Livraria do Advogado, 2012. 